\title{
タイヤチェーンによるモルタル,コンクリートの 摩耗特性に関する基礎的研究 \\ FUNDAMENTAL STUDY ON WEAR CHARACTERISTIC OF MORTAR AND CONCRETE BY TIRE CHAIN
}

$$
\text { 戸川 一 夫* • 小 柳 洽** }
$$

By Kazuo TOGAWA and Wataru KOYANAGI

\section{1.まえがき}

近年，わが国ではコンクリート舗装はアスファルト舗 装に比べてきわめて少なかったが，再び交通量の激増な らびに重車両交通の頻出に対して耐久性あるいは信頼性 の高いコンクリート舗装が再評価される機運にある1. コンクリート舗装の品質向上などに関する研究はいろい ろな角度からなされているが，今な扮究明改善すべき点 が多くみうけられる. 特に交通荷重の苛酷な繰り返しに 対してのコンクリート表面の摩耗とその修繥の問題が舗 装版自体の強度増強よりも, さらに重大な問題になる場 合も考えられる. 特に寒冷地などでのタイヤチェーンに よるコンクリート舗装の摩耗損傷は解明すべき重要な課 題のひとつとなっている.

現時点ではコンクリートの摩耗特性に関する研究は少 なく, 数人の研究者 ${ }^{22 \sim 5}$ によりコンクリートの摩耗特性 を支配する配合要因として, 細粗骨材のすりへり特性, 粒度, 粒径, 形状および使用量, 水セメント比あるいは 粗骨材とモルタルとの界面性状などが報告されている.

本研究はタイヤチェーンを用いてモルタル, コンクリ 一トの摩耗特性を実験的に求めるとともに, タイヤチェ 一ンによる摩耗作用を衝撃ならびにひっかき作用と想定 して, 摩耗粉の生成を絽り返し疲労によるひびわれ進展 の結果と結びつけて機構的な解明を試み, さらにモルタ ル,コンクリートの耐摩耗性の向上をひびわれ進展性状 すなおち破壊過程におけるフラクチャタフネス（破壊靭 性)の面から考察しょうとするものである.

\section{2. モルタル, コンクリートの摩耗機構に関す る仮説}

* 正会員 工修 和歌山工業高等専門学校助教授 土木工学科 ** 正会員 工修 京都大学助教授 工学部土木工学科
摩耗現象を分類する場合, J.T. Burwell ${ }^{6}$ 注凝着摩耗, 研削摩耗, 腐蝕摩耗および疲労摩耗の 4 つのいずれかで 説明できるとしている.

金属材料の凝着摩耗機構に関して, E. Rabinowicz') は摩耗をうけた凝着部の破壊の発生を Griffith の破壊 条件と同じように凝着部に蓄積されている弾性エネルギ 一の解放による表面の生成として考えている.これによ ると, 図一1 のように接触点 1 点につき 1 個の摩耗粉の 発生を考えて, 球 (半球) に貯わえられている弾性エネ ルギー $E_{e}$ は初期みかけ応力 $\sigma$ が材料の降伏応力 $\sigma_{y}$ であると仮定すれば,

$$
\begin{aligned}
& E_{e}=\left(\frac{\nu^{2} \sigma_{y}{ }^{2}}{2 E}\right)\left(\frac{\pi a^{3}}{12}\right) \\
& \text { ここに, } \\
& \nu: \text { ポアソン比 } \\
& \sigma_{y}: \text { みかけの降伏応力あるいは最大応力 } \\
& E: \text { 弾性係数 }
\end{aligned}
$$
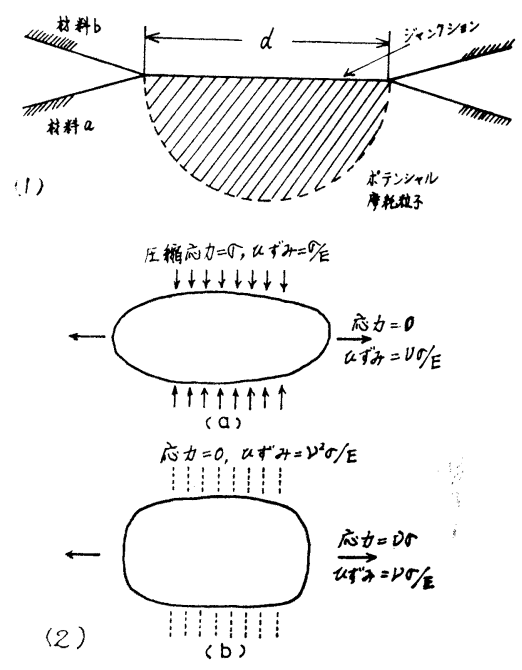

図一1（1）摩耗粉のモデル，(2) 摩耗粉の応力とひずみ との仮定, (a) 摩耗粉形成時, (b) 忍力解放後 
$a:$ 摩耗粉の粒径

界泊に作用する付着エネルギー $E_{a}$ は

$$
\begin{aligned}
& E_{a}=W_{a b}\left(\frac{\pi a^{2}}{4}\right) \\
& \text { ここに, }
\end{aligned}
$$

$W_{a b}:$ 引合ら材料間の結合力（表面エネルギー） 一つの摩耗粉の発生は $E_{e} \geq E_{a}$ のときに生成される とすると, 摩耗粉の平均粒径は

$$
a \geq \frac{6 E W_{a b}}{\nu^{2} \sigma_{y}{ }^{2}}
$$

さらに上式を簡単化するために， $\nu^{2}$ はほとんどの材料 に対して一定とし $\left(0.1\right.$ としている)，E/ $\sigma_{\boldsymbol{y}}$ はほとんど の材料について大略一定と考え, $\sigma_{y}$ は硬さに比例する とすれば, 摩耗粉の大きさは表面エネルギーの硬さに対 する比に比例することとなる.

この理論はあくまでも金属材料の凝着摩耗機構を解明 し, 摩耗を定量的に把握するために展開されたものであ る.しかしながら, 現在, 金属材料の凝着摩耗機構に関 してこの理論の適用はかならずしも抵抗なく受け入れら れているわけではない. それに対する反論として, 一般 に金属材料はある程度の塑性変形を生ずるため Griffith の仮説が適用できるところの脆性材料ではないこと，ま た, 摩耗粉の発生と成長過程に関して, 金属結合は脆性 材料の結合性状と違って, その結合力が強いために, 摩 耗粉が発生しかけてもただちに 1 個の摩耗粉として生成 されることが少なくて, 瞬間的に移着現象 ${ }^{8)}$ を生じて, 一度発生した摩耗粉が相手方母材表面に移着していくつ か集まり，その集合体がある大きさに達してはじめて母 材から欠落した摩耗粉となるといらこと, すなわち, 欠 落した摩耗粉の径は Rabinowicz の理論によって算定さ れる值とは異なる場合があること,さらには金属材料は 酸化摩耗の形態を取りやすいため, 摩耗粉の生成がその 場の雰囲気（主として酸素の有無）や摩耗試験速度（主 として酸素吸着作用の可否) に依存 ${ }^{9}$ して, 摩耗現象に 初期摩耗と定常摩耗とが現われることなどがあげられて いる.

しかしながら, 上述の論議はモルタル, コンクリート などのように粒子結合力の弱い, 摩耗粉が移着生長過程 をともないがたい脆性な物質, くわえて酸化摩耗の形態 をとらないと考えられる物質を取り扱ら場合にはあまり 考虑しなくてもよいと思われる。ここで, タイヤチェー ンによるモルタル，コンクリートなどの摩耗特性が衝撃 あるいはひっかき作用による繰り返し疲学の結果である と考えるならば, Rabinowicz の理論は资量的に金属材 料などの摩耗特性を説明しようとする場合よりも，むし ろ脆性材料であるコンクリートなどに対して衝撃による 表面部の微細なひびわれ進展とその結果から摩耗粉が発 生するという繰り返し疲労摩耗の形態を説明し, 発生し
た摩耗粉の粒径分布に基ゔいて脆性材料の摩耗性状を究 明する場合に対してより有用性が認められると考えるこ とができる.

ところで, 上記の観点から Rabinowicz の理論をモル タル,コンクリートなどの脆性材料の摩耗特性の解析に 適用しようとする場合, 材料の定数である表面エネルギ 一 $W_{a b}$ の真值を明確にしうる必要があるがコンクリー トのような多相材料に対してはその真值を測定する方法 は確立されていない.したがって, 本研究では表面エネ ルギーに関してはこれと巨視的かつ間接的に結びつきを 持ち, また破壊過程におけるフラクチャタフネスを量的 に表わす有効なパラメーターであると考えられてい る(0),11) 限界ひずみエネルギー 解放率（フラクチャタフ ネス） $G_{c}{ }^{12)}$ を採用し，さらには表面エネルギーとは比 例しないが，ひびわれ先端領域の応力状態と関連つけら れる応力拡大係数 $K_{c}{ }^{13)}$ も付加的に採用してみた. な お， $K_{c}$ 值の算定については数々の報告がなされている が14), いまだ十分には確立されていないと考えられ, 本 研究では $K_{c}$ の算定は 3. (3) で示している式を用いた.

\section{3. 実験 概 要}

\section{(1) 使用材料}

セメントは普通ポルトランドセメントを用いた，細骨 材は川砂（日高川産, 比重 2.49) 扝よび人工軽量砂 (大 阪セメント社製，比重 1.92）を用いた. 粗骨材は石灰岩 砕石（日本セメント高知県吉良ケ峰鉣山産, 比重 2.69), 安山岩砕石 (香川県仲多度郡猫山産, 比重 2.57), 硬質 砂岩砕石 (和歌山県日高郡由良産, 比重 2.60), 川砂利 (和歌山県有田川産, 比重 2.59) および人工軽量粗骨材 （大阪セメント社製，比重 1.40）を用いた. 細粗骨材は あらかじめふるい分けしておいて所定の粒度に調整し た.用いた細粗骨材の粒度曲線を図一2 に示す.

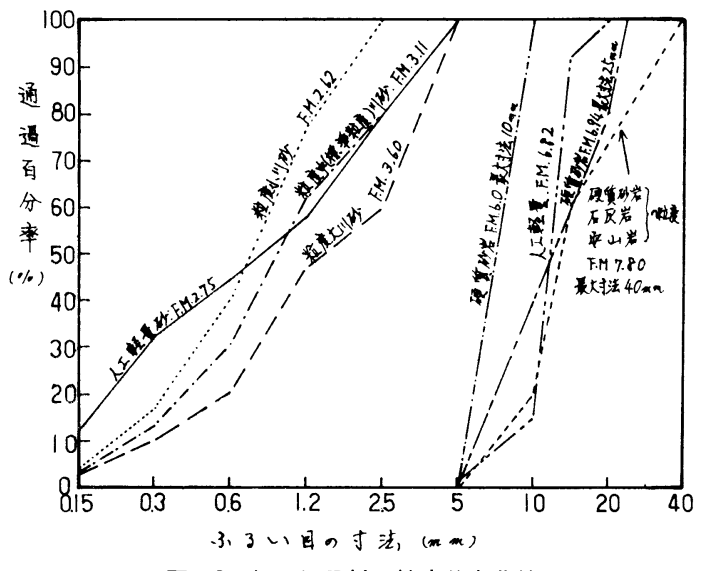

図一2 細・粗骨材の粒度分布曲線 


\section{(2) 摩耗試験方法}

摩耗試験用供試体 は $15 \times 15 \times 53$ $\mathrm{cm}$ の角柱供試体であり, 同一配合 供試体は 2 本隻備し，摩耗試験には 供試体打込 み底面部を試験に供し た. 摩耗試験に供試体打込底面部を 供試させたのは供試体表面仕上げ部 を用いた場合に，表面仕上げ性状の 差異が摩耗特性に影響することもあ ると考えられるので，その影響が現 れない上らに考慮した。供試体は主 として試験日まで水中養生 $\left(20^{\circ} \mathrm{C} \pm\right.$ 2 deg.) し, 試験は材令 28 日で行 った.

摩耗試験機はタイヤチェーンをと りっけた回転するタイヤ部と摩耗試 験供試体を水平往復運動させる装置 を組み合わせたものである（写真一 1 および図一3 参照). 固定軸にとり つけられた回転夕イヤ部は走行時速

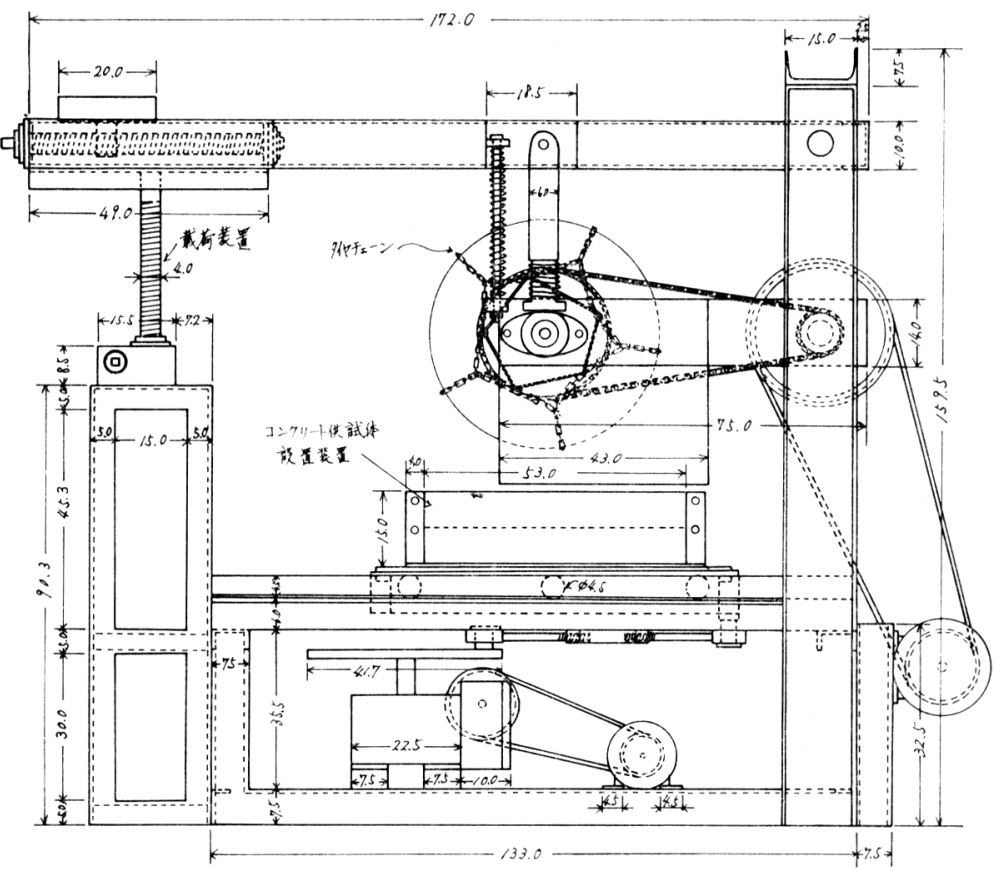

図一3 摩耗試験機の機構図

た。な扔，このすき間は摩耗試験中 10 分間ごとに調整 され，タイヤチェーンによって供試体に与えられる衝撃 仕事が試験中ほぼ一定になるようつとめた.

試験時の環境条件は主として室内気中乾燥状態（試験 中室内温度 $28^{\circ} \mathrm{C} \pm 3 \mathrm{deg}$.) とした. なお, 摩耗特性は環 境温度によって変化すると考えられるので, 試験は温度 变化の幅が小さくなるよう短期間に実施した．また夕イ ヤチェーンが供試体表面を衝撃することによって，供試 体表面の温度が変化すると考えられるが，この変化は全 実験を通じてほぼ同一条件であるとみなした。試験は一 つの供試体につき 60 分間行い, 10 分間ごとに供試体の 重量減少量を測定し, 試験終了後供試体の摩耗深さを図 -4 亿示寸方法で 1 個の供試体につき図に示寸 3 箇所で の摩耗深さを中央部 $3 \mathrm{~cm}$ 間について測定し, 平均值を

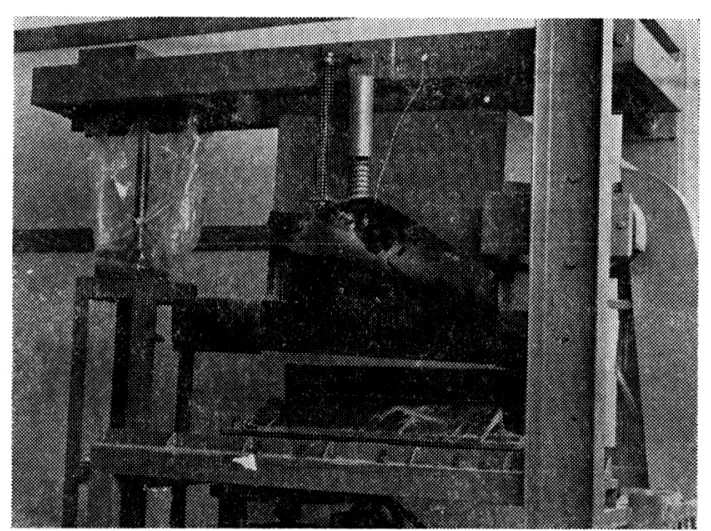

写真一1 摩 耗 試 験 機

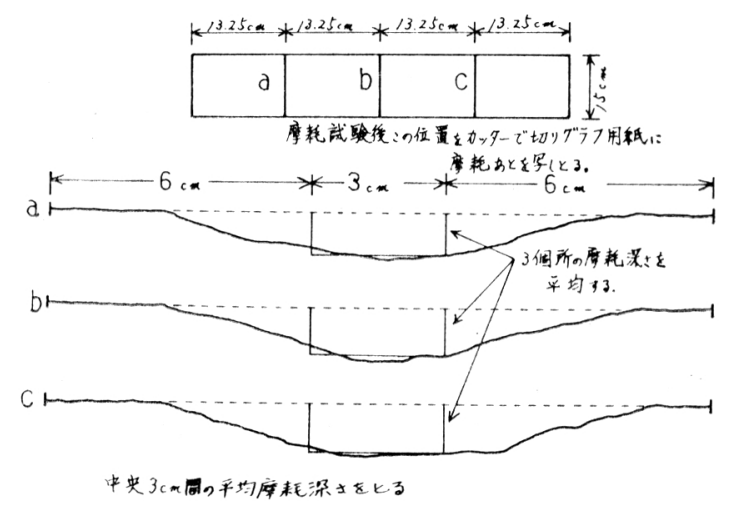

図-4 摩耗深さの測定方法 
求めて摩耗媣さとした．また，タイヤチェーンは摩耗試 験供試体 1 個ごとに新しいものを使用した. 摩耗粉の採 集方法は摩耗試験機をビニールシートで密封し, 床上に もビニールシートを敷きつめて堆積した摩耗粉を集め た. 摩耗粉の粒度分析は網子るい方法によって行い, 摩 耗粉の平均粒径は重量割合で $50 \%$ 通過するときの粒径 と定めた.

\section{（3） $\boldsymbol{G}_{c}$ およひ $\boldsymbol{K}_{c}$ の算定方法}

$G_{c}$ さらには $K_{c}$ の算定には引張側中央部に開角 $30^{\circ}$, 深さ $1.5 \mathrm{~cm}$ の切欠きをもつ $10 \times 10 \times 40 \mathrm{~cm}$ の供試体 を同一配合につき 4 本用意し, 試験は切欠き部をスパン $(30 \mathrm{~cm})$ の引張側中央部に位置させて, 3 等分点載荷曲 げ試験方法によった. 圧縮強度, 動弹性係数ならびにポ アソン比は $\phi 10 \times 20 \mathrm{~cm}$ の円柱供試体を同一配合につき 3 本用意して求めた。 $G_{c}{ }^{12)}$ ならびに $K_{c}{ }^{13)}$ は次の式に よって求めた.

$$
\begin{aligned}
& G_{c}=\frac{\left(1-\nu^{2}\right) \sigma_{n}^{2} \cdot h}{E} \cdot f(c / d)(\mathrm{kg} / \mathrm{cm}) \\
& K_{c}=\left(\frac{E G_{c}}{\pi\left(1-\nu^{2}\right)}\right)^{1 / 2}\left(\mathrm{~kg} / \mathrm{cm}^{3 / 2}\right) \\
& こ こ に, \\
& f(c / d)=\frac{\pi c}{d}\left(1-\frac{c}{d}\right)^{3} \\
& \nu: \text { ポアソン比 } \\
& E: \text { 弹性係数 }\left(\mathrm{kg} / \mathrm{cm}^{2}\right) \\
& \sigma_{n}:=\frac{6 M}{b h^{2}} \text { 切欠き底部のみかけの応力 }\left(\mathrm{kg} / \mathrm{cm}^{2}\right) \\
& M: \text { 単純ばり支間中央部（切久き部）の曲げモー } \\
& \quad \text { メント }(\mathrm{kg} \cdot \mathrm{cm}) \\
& b: \text { 供試体の幅 }(\mathrm{cm}) \\
& c: \text { 切欠きの深さ }(\mathrm{cm}) \\
& \mathrm{d}: \text { 供試体の高さ }(\mathrm{cm}) \\
& h=d-c(\mathrm{~cm})
\end{aligned}
$$

\section{（4）硬さ試験方法}

コンクリートの硬さに関する明確な定義はいまだ確立 されていないと考えられるが, 本実験ではシュミット八 ンマーテストによる反発係数を硬さの指標とした.

\section{（5）モルタル，コンクリートの配合計画}

モルタルおよびコンクリートの配合は限界ひずみエネ ルギー解放率 $G_{C}$ あるいは応力昖大係数 $K_{c}$ に影響す ると考えられる配合要因 ${ }^{10), 11)}$ を取り上げて基礎的な実 験を計画した。したがって, 実際に用いられている舗装 用コンクリートの配合とは多少異なっている.モルタル の配合は水セメント比を 40,50 および $60 \%$ とした場 合, 細骨材の粗粒率を $2.61,3.11$ および 3.60 と変化
させた場合, セメント砂比を $1: 1,1: 2$ および $1: 3$ とした場合, 細骨材に人工軽量砂を用いた場合を計画し た. コンクリートの配合は水セメント比, 砂セメント比 を一定にして, 粗骨材量を容積割合で 10,30 および $50 \%$ とした場合, 粗骨材の最大寸法を 10,25 および $40 \mathrm{~mm}$ とした場合, 使用粗骨材種類を変化させた場合 を考えた。

\section{4. 実験結果とその考察}

実験結果を表一1 に示す。

\section{（1）モルタル，コンクリートの摩耗形態}

材料の摩耗特性を究明していく過程で摩耗現象の時間 的な遷移を明らかにしていくことはきわめて大切なこと である.

図一5にモルタルならびにコンクリートの摩耗損量と 時間との関係についての代表的な結果の一例を示す.タ イヤチェーンによるモルタル, コンクリートの摩耗特性 は摩耗面の表面状態が一定している処女面摩耗に匹敵 し, 摩耗割合は時間的に一定で摩耗量は摩耗試験時間 （衝撃回数）に比例して増加する傾向を示しており，定 常摩耗 (摩耗割合が時間とともに減少して一定の摩耗量

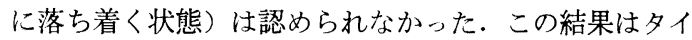
ヤチェーンによるモルタル，コンクリートの摩耗は試験 中発生した摩耗粉の飛散がはげしいため, 発生した摩耗 粉の蓄積による表面の保護効果がなされないこと，また 一たん取られた摩耗粉がまたもとの面に再転移する現象 がないこと,さらには金属材料などのように速度依存性 のある酸化摩耗の形態を取らないで，すなわち摩耗現象 が摩耗試験速度にそれほど左右されないといったことを 立証していると考えられ，2. で述べた仮説が成り立つ と考えられる.

なお，この結果の傾向はモルタルには終始強く現われ るが、コンクリートについては粗骨材の存在が摩耗特性 に若干影響する．たとえば摩耗抵抗性の大きい粗骨材を 用いたコンクリートでは摩耗試験開始後数十分経過する

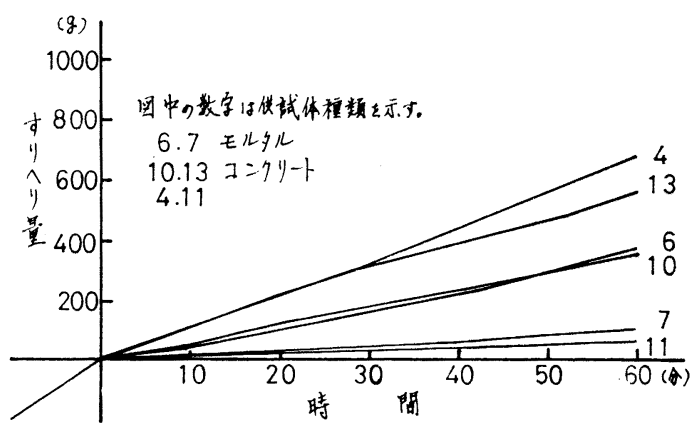

図一5 摩耗損量と試験時間との関係の一例 
表一1 各種配合のモルタルおよびコンクリートの強度特性と摩耗深さ

（実験条件：衝擊力, 鉛直方向 $0.183 \mathrm{~kg} \cdot \mathrm{m}$, 水平方向 $0.598 \mathrm{~kg} \cdot \mathrm{m}$ )

\begin{tabular}{|c|c|c|c|c|c|c|c|c|c|c|c|c|c|c|c|}
\hline & 供試体種類 & $\begin{array}{l}\text { 永七メン } \\
\text { 阝皆 } \\
(\%)\end{array}$ & 磁メント & 砂粒度 & \begin{tabular}{|l}
$\mid$ 粗骨材量 \\
$($ (容積\%)
\end{tabular} & $\begin{array}{l}\text { 曲1強度 } \\
\left(\mathrm{kg} / \mathrm{cm}^{2}\right.\end{array}$ & 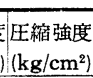 & 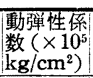 & $\begin{array}{c}G_{c} \\
\left(\times 10^{-2}\right. \\
\mathrm{kg} / \mathrm{cm})\end{array}$ & $\begin{array}{c}K_{c} \\
(\mathbf{k g} / \mid \\
\left.\mathrm{cm}^{3 / 2}\right)\end{array}$ & 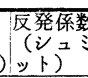 & $\begin{array}{l}\text { 平均粒径 } \\
(\mathrm{mm})\end{array}$ & 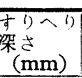 & 備 & 考 \\
\hline 1 & $モ ル 夕 ル$ & 50 & $1: 2$ & 中 & -- & 44 & 443 & \begin{tabular}{|l|}
3.5 \\
\end{tabular} & \begin{tabular}{|l|}
1.29 \\
\end{tabular} & \begin{tabular}{|l|}
39.08 \\
\end{tabular} & 24 & 0.14 & 6.0 & - & \\
\hline 2 & モル夕ル & 40 & $1: 2$ & 巾 & - & 56 & 472 & 3.8 & 1.79 & 49.28 & 26 & 0.24 & 4.9 & - & \\
\hline 3 & $€ ル タ ル$ & 60 & $1: 2$ & 中 & .... & 33 & 285 & 3.0 & 0.85 & 29.37 & 16 & 0.14 & 8.2 & $\ldots$. & \\
\hline 4 & $モ ル タ ル$ & 50 & $1: 2$ & 人亡軽 & $\ldots$ & 40 & 299 & 2.2 & 1.29 & 31.45 & 17 & 0.12 & 10.4 & & \\
\hline 5 & $モ ル 夕 ル$ & 50 & $1: 1$ & 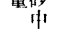 & ... & 42 & 372 & 2.8 & 1.34 & 36.43 & 20 & 0.13 & 7.4 & & \\
\hline 6 & $€ ル \& 儿$ & 50 & $1: 3$ & 中 & $\ldots$ & 40 & 426 & 3.3 & 1.28 & 37.51 & 22 & 0.14 & 5.9 & $\ldots$ & \\
\hline 7 & $€ ル$ 多 & 50 & $1: 2$ & 大 & $\ldots$ & 46 & 423 & 3.7 & 1.33 & 40.45 & 22 & 0.14 & 1.0 & $\ldots$ & \\
\hline 8 & $€ ル 夕 ル$ & 50 & $1: 2$ & 小 & $\ldots$ & 44 & 419 & 3.4 & 1.22 & 37.19 & 22 & 0.11 & 6.6 & - & \\
\hline 9 & コンクリート & 50 & $1: 2$ & 中 & 0.1 & 43 & 421 & 3.9 & 1.21 & 40.45 & 22 & 0.14 & 7.6 & 硬質砂㞸 & \\
\hline 10 & コンクリート & 50 & $1: 2$ & 中 & 0.3 & 44 & 459 & 4.4 & 1.10 & 40.45 & 23 & 0.20 & 4.6 & 硬質砂岩 & \\
\hline 11 & コンクリート & 50 & $1: 2$ & 中 & 0.5 & 45 & 467 & 5.1 & 1.19 & 43.74 & 23 & 0.16 & 1.2 & 硬質砂岩 & \\
\hline 12 & コンクリート & 50 & $1: 2$ & 中 & 0.3 & 46 & 439 & 4.6 & 1.36 & 44.14 & 23 & 0.16 & 3.4 & 川砂 利 & \\
\hline 13 & コンクリート & 50 & $1: 2$ & 中 & 0.3 & 43 & 435 & 5.3 & 0.94 & 43.03 & 22 & 0.13 & 7.8 & 石兏岩 & \\
\hline 14 & コンクリート & 50 & $1: 2$ & 中 & 0.3 & 51 & 533 & 4.6 & 1.41 & 46.35 & 28 & 0.13 & 5.5 & 安山岩 & \\
\hline 15 & コンクリート & 50 & $1: 2$ & 中 & 0.3 & 40 & 401 & 3.1 & 1.09 & 33.47 & 20 & 0.09 & 8.1 & 人工軽量 & \\
\hline
\end{tabular}

仯粒度，大，中，小心図一 -2 参照，摩籷粉の平均粒径は重量割合て $50 \%$ 通過与万時の粒径

（実験条件: 衝撃力, 鉛直方向 $0.124 \mathrm{~kg}-\mathrm{m}$, 水平方向 $0.450 \mathrm{~kg}-\mathrm{m}$ )

\begin{tabular}{l|l|l|l|l|l|l|l|l|l|l|l|l|l|l|l}
\hline 16 & コンクリート & 50 & $1: 2$ & 中 & 0.3 & 51 & 356 & 3.6 & 2.13 & 44.80 & 26 & 0.21 & 2.7 & 硬質砂岩, 乾嬠 \\
17 & コンクリート & 50 & $1: 2$ & 中 & 0.3 & 50 & 309 & 2.9 & 2.11 & 44.40 & 25 & 0.23 & 5.3 & 硬質砂岩, エチンン \\
18 & コンクリート & 50 & $1: 2$ & 中 & 0.3 & 45 & 272 & 2.8 & 1.61 & 39.75 & 22 & 0.22 & 6.1 & 硬質砂岩, ケロンン \\
19 & コンクリート & 50 & $1: 2$ & 中 & 0.3 & 46 & 344 & 2.9 & 1.42 & 40.62 & 18 & 0.30 & 6.0 & 硬質砂岩, 水 \\
20 & コンクリート & 50 & $1: 2$ & 中 & 0.3 & 48 & 302 & 2.6 & 2.12 & 42.70 & 25 & 0.22 & 4.5 & 硬質砂岩, 最大寸法 \\
21 & コンクリート & 50 & $1: 2$ & 中 & 0.3 & 49 & 292 & 2.6 & 2.23 & 43.70 & 23 & 0.22 & 5.6 & 硬質砂岩, 最大寸法 \\
\hline
\end{tabular}

表面張力 : ケロンン 24.9 , エチレンクリコール 46.7 , 水 $70.4(\mathrm{dyne} / \mathrm{cm}) 25^{\circ} \mathrm{C}$ 供試体 No. 16, 20, 21 注水中養生 24 日間以後 2 日間 $110^{\circ} \mathrm{C}$ 絶乾 供試体 No. 17, 18, 19 はをれぞれの液体に浸漬して養生.

とコンクリートの摩耗割合が粗骨材の表出によってやや にぶる傾向がみられる．しかしその傾向は定常摩耗を意 味するものではないと考えられる.

\section{（2）摩耗粉の性状からみたモルタル，コンクリート の摩耗特性}

2. で述べた Rabinowicz の摩耗粉の平均粒径に関す る理論によれば，表面エネルギーはパラメーター（硬さ ×摩耗粉の平均粒径）に比例するということに基ゔい て，本論では表面エネルギーをこれと巨視的に結びつく $G_{c}$ 值で代用して, 材料定数としての $G_{c}$ がモルタル, コンクリートの摩耗特性を有効に表わす指標となるかど らかを検討した。

まず使用する粗骨材自身のすりへり特性と摩耗粉径と の関倸について検討を加えた.

ロスアンゼルス寸りへり試験によって用いた各種粗骨 材のすりへり減量とすりへり粉の平均粒径との関係を図 -6 に示す. 各種粗骨材のすりへり減量特性はすりへり 粉の平均粒径から推察できるものと考えられ, すりへり 減量の大きい骨材ほどすりへり粉の平均粒径はしだいに 小さくなる傾向がある．また粗骨材自身のすりへり特性 （ロスアンゼルス試験）について，表面エネルギーの見 地からみた破壊特性でもって説明できるかを調べた結果 が図一7に示されている．これらの粗骨材の硬さ值はそ

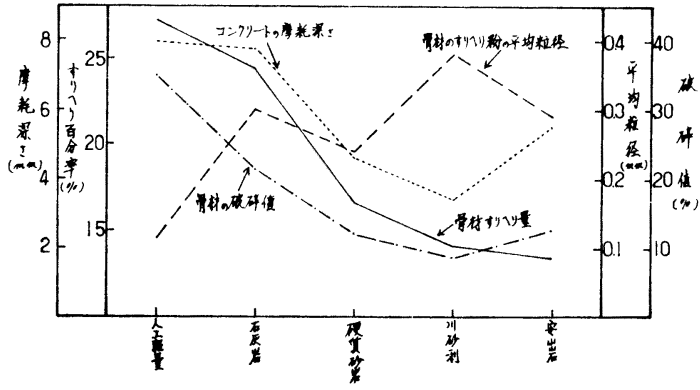

図一6 粗骨材のすりへり量破砕值およびすりへり粉の 平均粒径とコンクリートの摩耗深さとの関係

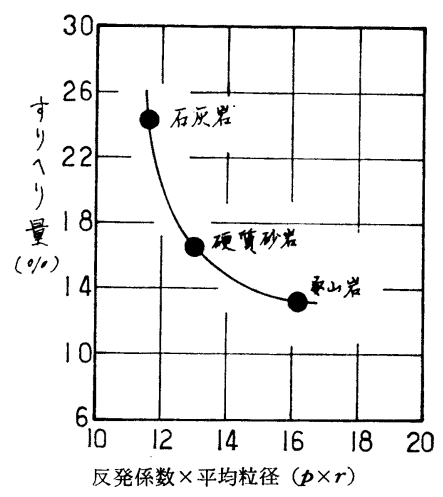

図一7 粗骨材のすりへり臬とパラメーター （反発係数 $\times$ 摩耗粉平均粒径）との関係 
れぞれの母岩について測定している.この結果より粗骨 材自身のすりへり減量特性とパラメーター（硬さメすり へり粉の平均粒径）との間には相関関係がうかがわれ る.なお，人工軽量骨材および川砂利については反発倸 数が測定しにくいためにデータが示されていない.

次に各種のモルタル, コンクリートの摩耗特性がパラ メーター（硬さ $\times$ 摩耗粉の平均粒径）で説明できるかを 図一8で考察した。同図から実験上のばらつきはあるも のの両者の閒には相関関倸があることがほぼ判明した。 また図一9 から $G_{c}$ はパラメーター（硬さ人摩耗粉の雨。 均粒径）とほぼ直線関係にあることが明らかとなった。 な掞 $K_{c}$ もパラメーター（硬さ $\times$ 摩耗粉の平均粒径）と 直線関係にあることがわかった (図一10 参照).

ここで, ひびわれの進展性状の差異がモルタル, コン クリートの摩耗特性の差異に対応するものであるかどう かを確かめるために同配合のコンクリートについて摩耗 試験前の養生条件を変化させた場合の実験を試みた. 実 験は摩耗試験前の 4 日前の養生条件を 4 種類つくり, 寸 なわち, 材令 24 日に供試体を水中から取り出して 2 日

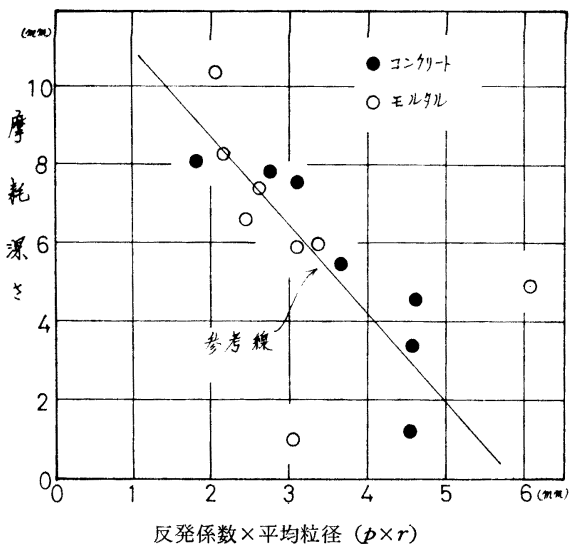

图一8 モルタル・コンクリートの摩耗深さとパラメーター （反発係数 $\times$ 摩耗粉平均粒径）亡の関係

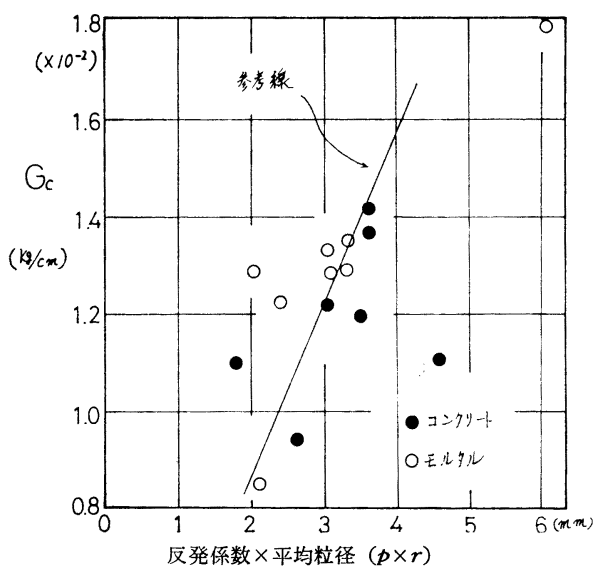

図一9 $G_{c}$ とパラメーター（反発係数 $\times$ 摩耗粉平均粒径） との関係

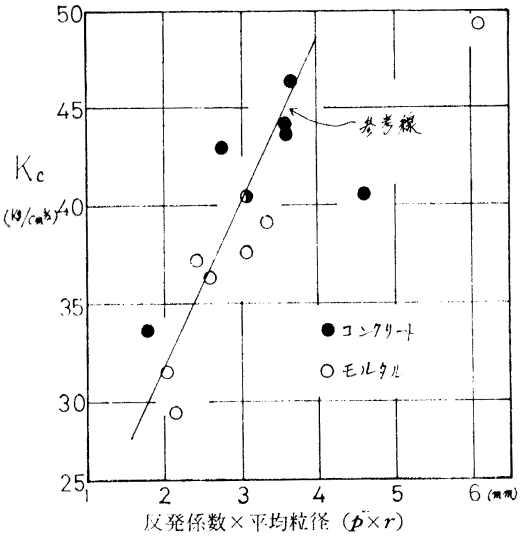

\section{図一10 $K_{c}$ とパラメーター（反発係数 $\times$ 摩耗粉平均粒径)} との関係

間は $110^{\circ} \mathrm{C}$ で絶乾状態にし, 後の 2 日間をそれぞれ, ゴム防湿袋に入れて湿気をしゃ断したもの，エチレング リコール液に浸せきしたもの，ケロシン液に浸せきした もの，水に浸せきしたものとした．試験時にもそれぞれ の液を摩耗供試体面上に少量ずつ流している。これらの 液体はそれぞれ液体の表面張力が異なっているものであ り, 大きな表面張力をもつ液体は小さな表面張力の液体 よりも，その分子が物理吸着することによって固体の表 面エネルギーを低下させて, 微少割れの伝播をより容易 にすると結論ゔけられている ${ }^{15), 16)}$. 実験結果は図一11 に示すように表面張力のより大きな液体に浸せきしたコ ンクリートは摩耗損量がより大きくなる傾向があり，ひ びわれの伝播がより容易になされた結果ではないかと推 測される.

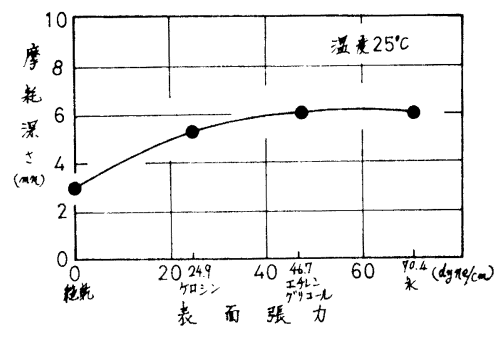

図一11摩耗深さと液体の表面張力との関係

したがって，上記結果を考え合わせるとタイヤチェー ンによるモルタル，コンクリートの摩耗特性は 2.の仮 説を裏付ける結果であると考えられ，コンクリートなど の摩耗特性に対して, 材料のひびわれ進展性状すなわち 破壊過程に扔けるフラクチャタフネスに基づいた繰り返 し疲労摩耗の立場からの研究は有効な方法であろう。

\section{5. むすび}

本研究はタイヤチェーンによるモルタルおよびュンク 
リートの摩耗特性に関して摩耗粉の発生が繰り返し疲労

によるひびわれ進展の結果であるとして, Rabinowicz の理論の適用性について検討し,さらにモルタル, コン クリートの耐摩耗性の向上の配合条件を破壊過程におけ るタフネスの面から考察したものである. 本実験結果を 要約すれば次のとおりである。

（1）モルタルならびにコンクリートの摩耗形態は摩 耗面の表面状態が一定している処女丽摩耗に四敵し，磨 耗制合は時間的に一定で摩耗最は摩耗時閒（衝撃可数） に比例して堌加し, 定常摩耗現象は認められない.

（2）モルタル扝よびュンクリートの摩耗特性は摩耗 粉の平均粒径に関する Rabinowicz の理論をもとにし て, パラメーター（硬さ $\times$ 摩耗粉の平均粒径）の関数で 表わされると考えられ, 摩耗粉の発生は繰り返し疲労に よるひびわれ伝播の結果であり，摩耗特性はひびわれの 伝播すなわち破壊過程に抢けるタフネスと関係すると推 測できる.

(3) モルタルおよびュンクリートの耐摩耗性の向上 をはかるには，より大きなフラクチャタフネスをもつ配 合条件を見つけだすことが一方法として考えられる。

謝辞 本研究を行うにあたって, 実験装置, 文献 などの面で多大なご指導をたまわりました建設省土木研 究所 柳田 力地質化学部長, 実験にご協力下さった和 歌山工業高等専門学校土木工学科 中本純次助手, 平野 順技官ならびに卒業研究生に深謝の意を表します.

\section{参 考 文 献}

1）高速道路调查会：コンクリート舗装の施工に閘与る検剖 報告書, 昭和 46 年 2 月。

2) C.L. a'Court : Mix Design and Abrasion Resistance of Concrete, Proc. of a Symp. on Mix Design and
Quality Control of Concrete, London, 5, 1954, pp. 77 91.

3) Fumihiko ŌHAMA : A Testing-Method for Resistance of Concrete to the Tractive Force of Water Current, Proc. of the Fifth Japan Congress on Testing Materials, Kyoto, 1962, pp. 118 122.

4）柳田 力・榑沼昌明：セメントコンクリート舗装の設部 施工技術の改善に関与る試験調查, 昭和 48 年, Private Communication.

5）三和・堀田・金子・飯田：コンクリート舗装のすりへり 抵抗に関与る公内試験, 日本滇路公団試験所報告, 沼和 45 年, pp. 18 31.

6) Burwell, J.T. : Wear, 1, 2, 1957, 築添正, 機械要素に 出ける摩耗の問題点, 日本機械学会関西支部第 49 回講 㴼会, 昭和 47 年, pp. 1 12 より.

7) Rabinowicz, E. : Friction and Wear of Materials, John Wiley and Sons, INC, 1965.

8）笛田 直・甘道英男：移着成長による摩耗粉の生成, 潤 滑, Vol. 17, No. 2, 昭和 47 年, pp. 96 101.

9）笹田 直: 摩擦による固体表面の損傷, 日本機械学会誌, Vol. 75, No. 641, 昭和 47 年, pp. 905 912.

10）小柳 洽・境 賢治：モルタル执よびコンクリートのク ラック伝播に関する 2,3 の考察，セメント技術年報, $\mathrm{XXV}$, 昭和 46 年, pp. 264 269.

11）戸川・佐藤・荒木：モルタルならびにコンクリートの夕 フネスに影響する要因, セメント技術年報, XXVII, 昭和 48 年, pp. 202 206.

12) Kaplan, M.F. : Crack Propagation and the Fracture of Concrete, Jour. of ACI, Vol. 58, No. 5, 1961, pp. $591 \sim 609$.

13）岡田 清・小柳 洽：コンクリートの破壊条件之破壊過 程, 材料, Vol. 20, No. 208, 昭和 46 年, pp. $2 \sim 12$.

14）小林昭一：コンクリートの破壊機構, コンクリート工学, Vol. 13, No. 2, 1975, pp. 1 11.

15）堀 素夫：セメント抢よびコンクリートの破壊現象に関 する確率論的研究, 東京大学博士論文, 昭和 36 年.

16) Vutukuri, V.S. : The Effect of Liquids on Tensile Strength of Limestone, Int. Jour. Rock, Mech. Min. Sci. \& Geomech. Abstract, Vol. 11, 1974, pp. 27 29.

(1974.12.23 ·受付) 